\title{
Quantitation of Leydig Cell in Testicular Biopsies of Gossypol Treated rats
}

\author{
Dr. Muhannad A. A. Al Bayaty \\ Physiology \& Pharmacology Department /Vet. Med. Collage / University of \\ Baghdad
}

\section{Summary}

Leydig cell density was evaluated quantitatively in bilateral testicular biopsies from twenty male rats of two equal groups Gossypol treated and control. The method utilized for this quantitation is based on the determination of total number of Leydig cells, Leydig cell clusters and seminiferous tubules in the entire histological section of each biopsy and the calculation of the following indices: mean Leydig cells per seminiferous tubule, mean Leydig cell clusters per seminiferous tubule and mean Leydig cells per cluster. A significant positive correlation between Leydig cells per tubule and Leydig cell clusters per tubule was demonstrated. The results of indices curve showed shifted all the curves to the right in Gossypol treated group, a significant reduction in plasma testosterone levels of Gossypol treatment group as compared to control group which is due to decrease in Leydig cells number, suggesting that determination of Leydig cell clusters per seminiferous tubule in testicular biopsies is an objective and clinically applicable method for quantitative evaluation of Leydig cell density and indirectly evaluated the secretary activity of the testicular Leydig cells. The results are attributed to the direct effect of Gossypol on secretary site of testosterone in Leydig cells or presumably indirect disturbance of hypothalamic - pituitary gland - Leydig cells axis. An Association of Gossypol treatment with Leydig cell hypo-function and decrease number of cells was noticed for the male rat testosterone level. To our knowledge this is the first report of quantitative analysis of Leydig cell density in rat with Gossypol treatment and it is suitable for clinical evaluation of testicular dysfunction.

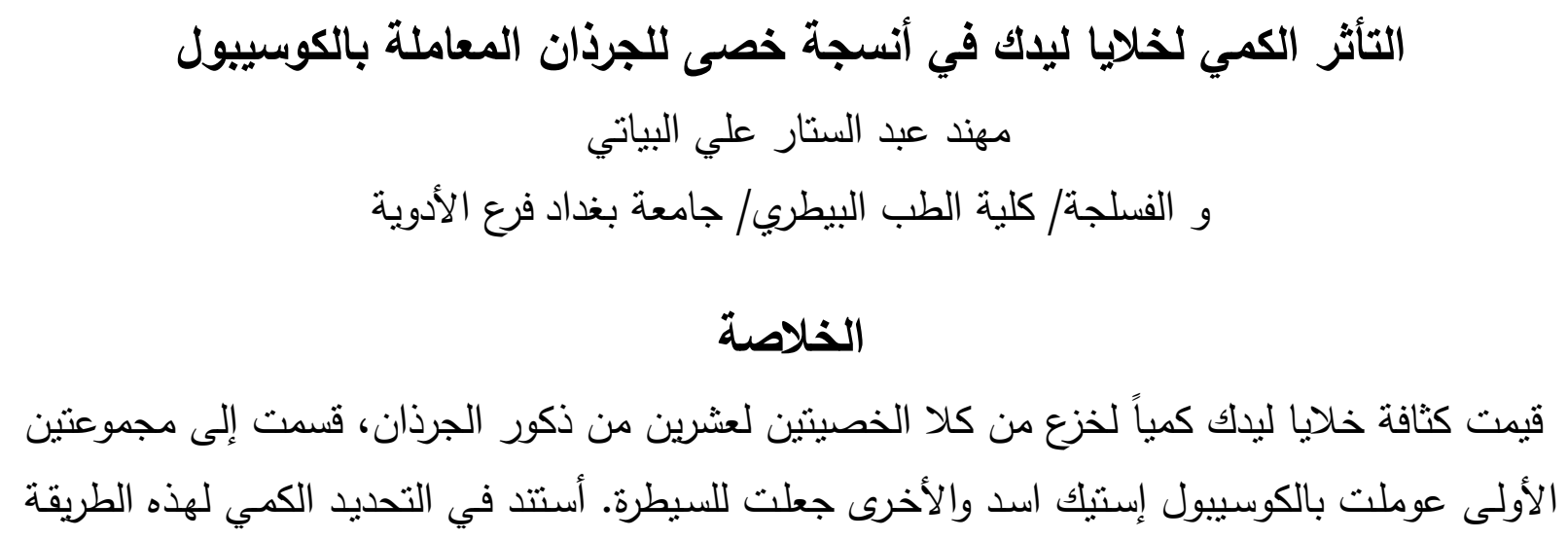


على عد كل من خلايا ليدك الكلي وتجمعات خلايا ليدك والنبييات الخصوية في الثرائح النسيجية للخزع

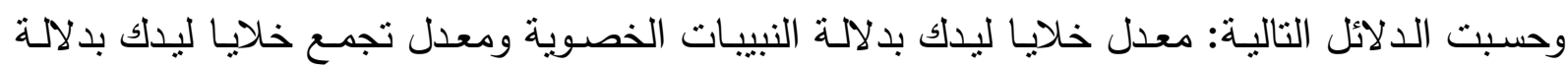

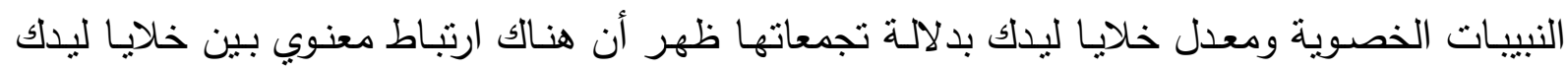

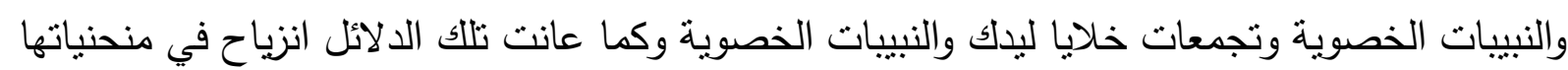

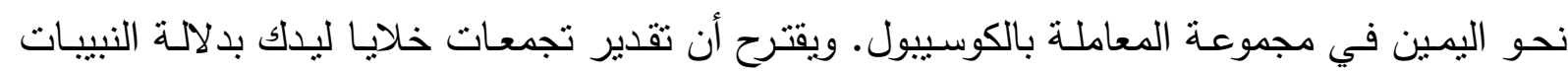
الخصوية في الخزع الخصوية طريقة تطبيقية موضوعية وسريرية لتقيبم كلاً من كثافة خلايا ليدك كمياً

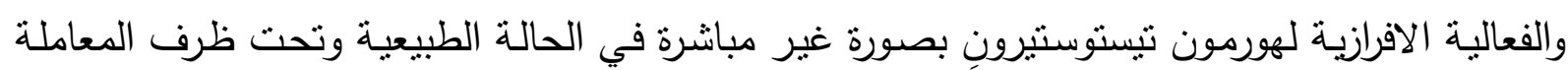

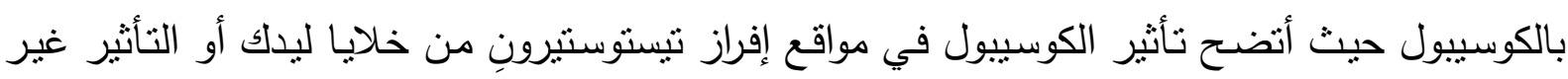

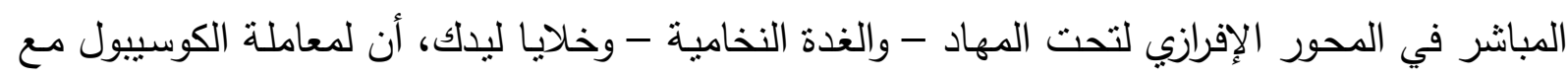
أنخفاض وظيفة خلايا ليدك أو نقص عددها تتوافق مع اختزال معنوي في مجموعة المعاملة بالكوسيبول

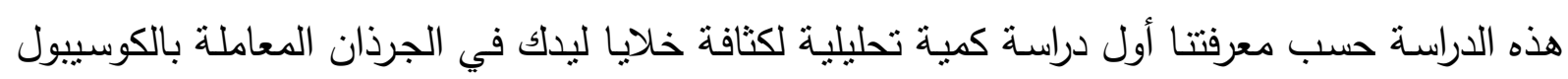
وتعد مناسبة توضح وتحليل لأي حالة سريرية جنسية.

\section{Introduction}

The evaluation of semen quality is a simple procedure easily performed in a clinical laboratory. The results of such analysis are helpful in evaluation of the fertility potential of the male (Zenick, et al 1994). Semen analysis, however, fails to shed any light on the etiology of testicular disorder leading to abnormal output of spermatozoa and consequently is of limited value in the diagnosis of the causes of azoospermic or oligospermic conditions. Endocrine evaluation of the infertile patient and objective quantitative analysis of the functional components of the testicular biopsy specimen may provide important information concerning the etiology and the pathogenesis and may in specific instances, serve as a helpful guide to therapy (Heler and leach., 1971).

In mice, the histological pattern of the seminiferous epithelium in infertile male induced by Gossypol (Cottonseed extract as a male contraceptive) has been described to reveal a certain degree of disorganization, exfoliated germ cells and diffuse vaculation in spermatogenic epithelium; intraepithelial vacuoles, or dearrangement of germ cells and the pachytene spermatocytes and step 7 spermatids, show pyknosis, degeneration and ghost cells with sever dissociation and swelling of these cells ( $\mathrm{Al}$ - Bayaty 1999). This description is compatible with the findings of low sperm counts and increased number of spermatozoa found in the semen suspension of such male mice.

However, these histological findings fail to explain either poor sperm motility or reduction in motility index (Su-ming et al., 1982), a dominant 
feature found in the sperm suspension of such made mice; the improvement in sperm motility the most important result of gossypol treatment (Ridley and Blasco, 1981).

A high intratesticular concentration of testosterone is essential for normal spermatogenesis as well as for the structural and functional integrity of the epididymis (Steinberger and Steinberger, 1972). Because sperm motility is acquired in the epididymis (Blandau and Rumery, 1964), MacLeod (2003) has reasoned that a motility defect in the semen may be due to failure of the epididymal epithelium to supply the necessary support for the spermatozoa. Androgens produced primarily by the Leydig cells, are essential for the normal function of the epididymis. Consequently, Leydig cell dysfunction may be a cause of inadequate sperm motility and thus impaired fertility (Brown, 1999). Indeed, several studies demonstrated that Leydig cell dysfunction in male animals and men with oligospermia may be responsible for their infertility (Rigau, et al, 2000). Despite the documented association between damage to the germinal epithelium and treatment of Gossypol, no consistent relationship with regard to the Leydig cells has been demonstrated, but we have ever of speculation study indirect the effect of Gossypol on the hypothalamic - pituitary - Leydig cell axis rather than exactly direct effect on Leydig cells (AL - Bayaty, 1999). Therefore this study is designed to shed the light on sough a simple, reliable and practically applicable method for qualitative analysis of Leydig cell density which was applied to the evaluation of Leydig cell density in infertile rats after Gossypol treatment.

\section{Materials and Methods}

Twenty male rats of (4) months of age, weighing $(80-120) \mathrm{g}$ were maintained under uniform environmental condition; temperature $(25-30) \mathrm{C}^{\mathbf{o}}$, (12) hours light and fed ad libidum.

The rats were divided into two equal groups randomly. One group was given gossypol $20 \mathrm{mg} / \mathrm{kg} \mathrm{BW}$ per day orally (98.87) \%, whereas the second group served as a control and were given normal saline. Each group was sacrificed after (42) days of treatment (one spermatogenesis cycle).

Sperm suspension from cauda of epididymis was prepared as described by Sakomoto and Hashimoto (1986). The sperm motility index was performed as described by Sokoloski et al. (1977).

Plasma testosterone concentration was measured by radioimmunoassay, (Smith, etal., 1976).

\section{Histology}

Fresh testes were fixed in Boin's fluid fixative and processed by stander histological methods. Sections $(5 \mu \mathrm{m})$ were stained with periodic acid Schiff hematoxylin (Dykes, 2001). The entire histological specimen for each biopsy 
was examined under the microscope (x100). The total number of seminiferous tubules, Leydig cell, Leydig cell clusters and the number of Leydig cell per clusters were counted, these data were used to calculate the following indices (Dykes, 2001 and Heller \& Leach 1972):

1. The mean number of Leydig cells per seminiferous tubule was obtained by dividing the total number of Leydig cells counted in the entire histological section by the total number of seminiferous tubules.

2. The mean number of Leydig cells per clusters was obtained by dividing the total number of Leydig cells found in clusters by the number of cluster counted in the entire section.

3. The mean number of Leydig cell cluster per seminiferous tubule was obtained by counting all clusters in the section and dividing by the number of the seminiferous tubules.

\section{Statistical analysis:}

Results are expressed as mean \pm SEM. We used F test: one-way analysis of variance and LSD in this study. Correlation and regression coefficient were obtained for comparisons between mean data of Leydig cell indices curves for gossypol and control groups. Differences between mean data were considered significant at $\mathrm{P}<0.01$ (Steel and Torrie, 1980).

\section{Results}

Sperm motility index sperm count and circulating testosterone level are shown in table $(1)$, there were significant decreased $(\mathrm{P}<0.05)$ after $(42)$ day treatment groups as compared with control group.

Table (1): Effect of 42 days treatment Gossypol by (40 mg/ kg BW/ day) on sperm motility index, sperm concentration and plasma Testosterone level of rats.

\begin{tabular}{|c|c|c|c|}
\hline Parameter & $\begin{array}{c}\text { Sperm motility } \\
\text { Index \% }\end{array}$ & $\begin{array}{c}\text { Sperm counts } \\
\times \mathbf{1 0}^{\mathbf{6}} \mathbf{~ m l}\end{array}$ & $\begin{array}{c}\text { Circulating } \\
\text { Testosterone } \mathbf{~ p g} / \mathbf{m l}\end{array}$ \\
\hline Control & $0.713 \pm 0.0022$ & $28.65 \pm 0.63$ & $4.97 \pm 1.05$ \\
\hline Treatment & $0.234 \pm 0.0016$ a & $8.51 \pm 0.42$ a & $1.06 \pm 0.48$ \\
\hline
\end{tabular}

Values are presented as mean standard error

Letter $\{a\}:(P<0.01)$ vs. Differences between treatment and control group.

In table (2), the number of seminiferous tubules, Leydig cell clusters and the total number of Leydig cells counted in the entire histological section of each groups are shown in Picture. A significant correlation $(\mathrm{P}<0.01)$ was found between the number of seminiferous tubules and the number of Leydig cell 
cluster (Fig. 1) in each group, however, the regression line was shifted to the right in Gossypol treated group.

Significant correlation $(\mathrm{P}<0.01)$ was found between the number of Leydig cells per seminiferous tubule and Leydig cell clusters per seminiferous tubule (Fig. 2) and between number of Leydig cells per seminiferous tubule and Leydig cell per cluster (Fig. 3) in control and Gossypol treated groups.

Table 2 : Number of semineferous tubules, Leydig cell clusters and Leydig cells in histological section of control and Gossypol treatment groups (40)mg/kg BW for (42) day.

\begin{tabular}{|c|c|c|c|}
\hline Parameter & $\begin{array}{c}\text { No. of } \\
\text { Semineferous } \\
\text { tubule }\end{array}$ & $\begin{array}{c}\text { No. of Leydig } \\
\text { cell clusters }\end{array}$ & $\begin{array}{c}\text { No. of Leydig } \\
\text { cells }\end{array}$ \\
\hline Group & $114.39 \pm 15.57$ & $124.80 \pm 15.93$ & $676.48 \pm 76.11$ \\
\hline Control & $126.34 \pm 14.69$ & $73.29 \pm 11.81$ a & $299.47 \pm 22.83$ a \\
\hline
\end{tabular}

Values are presented as mean \pm standard error.

Letter $\{\mathrm{a}\}:(\mathrm{P}<0.01)$ vs. Differences between treatment and control group.

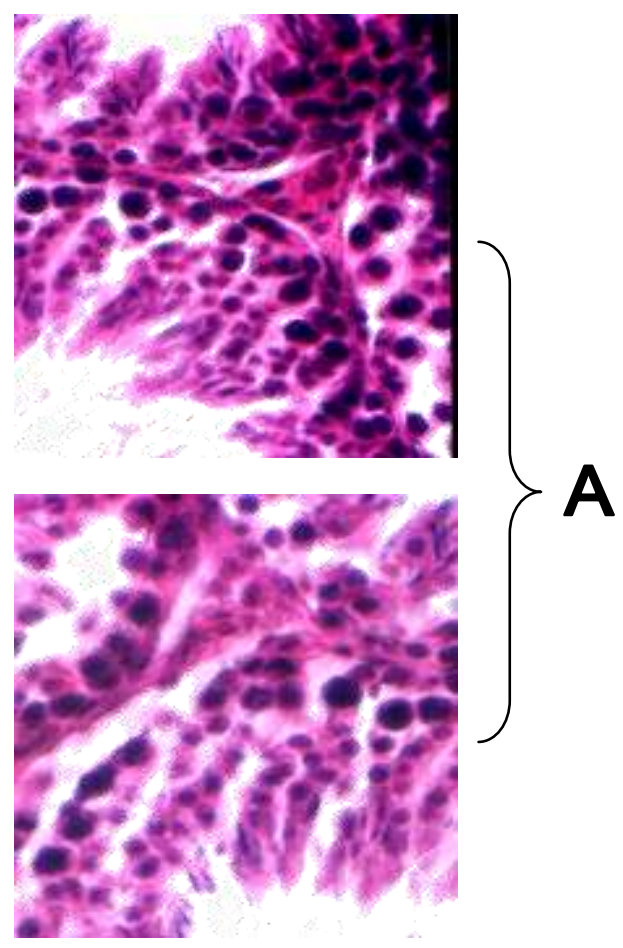

Picture (1)

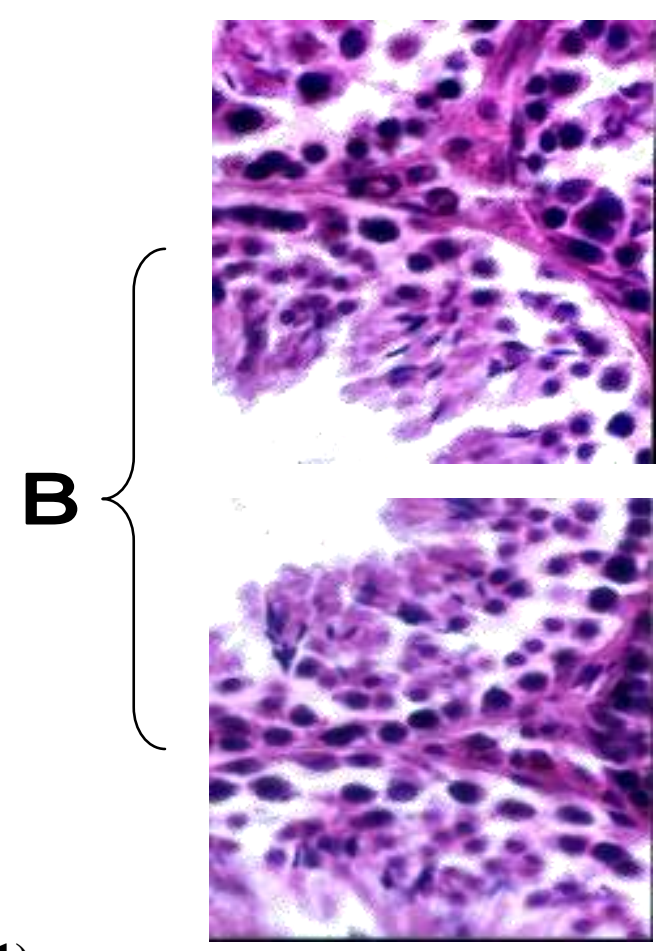

A) Cross section of Leydig cells from a control rat testis, showing the normal histological pattern of Leydig cell with orderly arrangement of Leydig cells clusters, surrounded between somniferous tubule periodic acid Schiff / hematoxylin $\times 500$. 
B) Cross section of Leydig cells of the rat testis treated with $20 \mathrm{mg} / \mathrm{kg}$. per day of Gossypol after (42)days: Notice atypical histological pattern of Leydig cell with derangements of cluster with fatty Leydig cell, unsecretory phase. Periodic acid Schiff / hematoxylin $\times 500$.

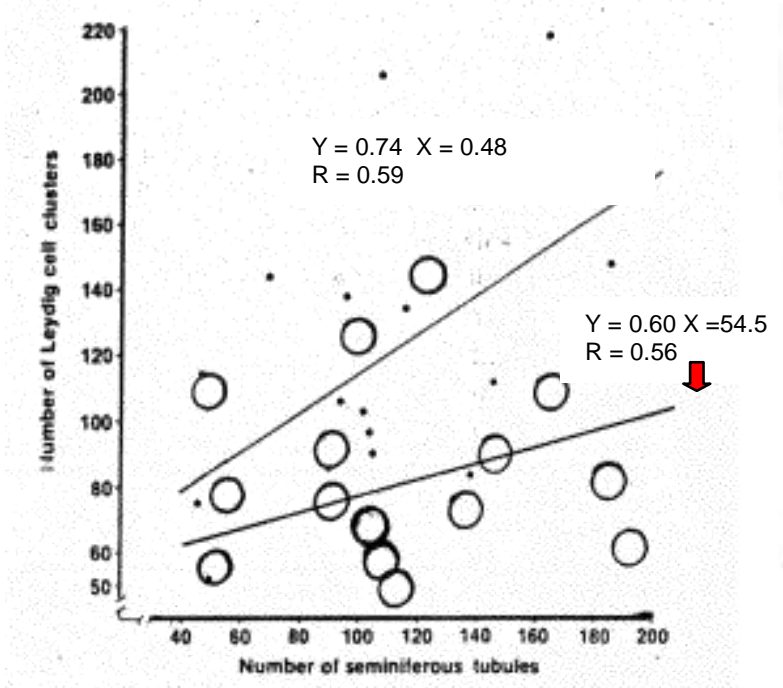

Fig. (1) Correlation of mean number of seminiferous tubules and mean number of Leydig cell clusters for the Gossypol $\square$ and control groups $(P<0.01)$.

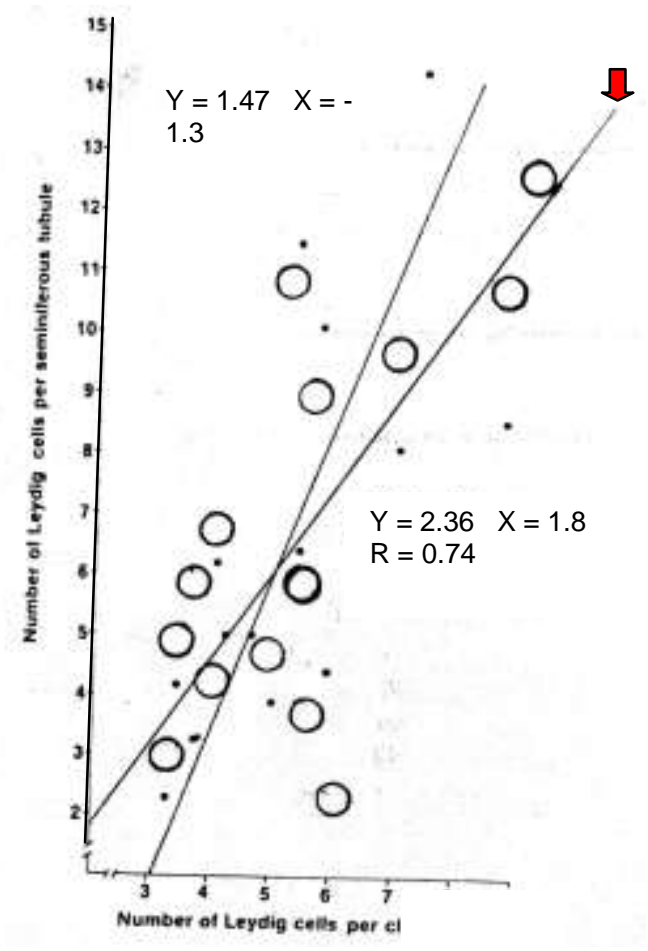

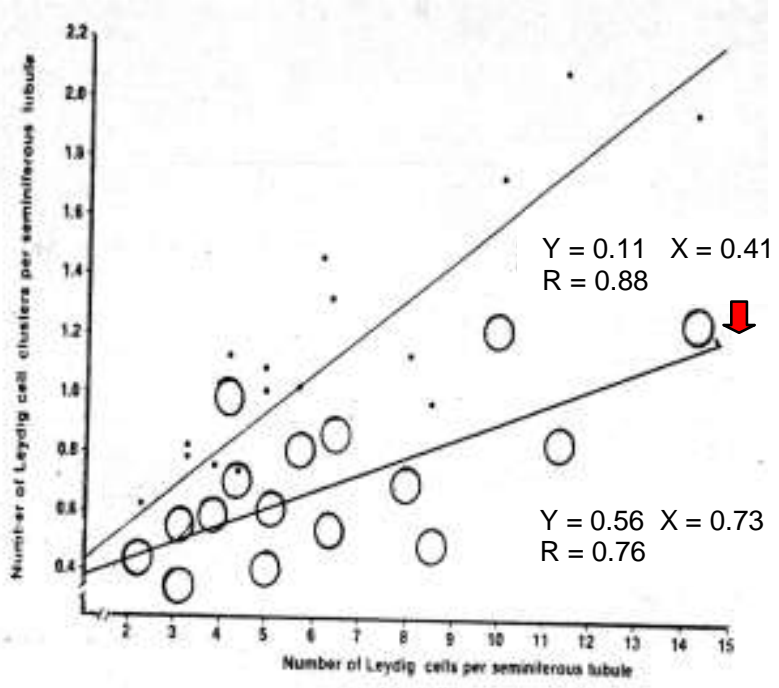

Fig. (2) Correlation of each Gossypol [] and control groups in correlation between mean number of Leydig cell clusters per seminiferous tubule $(P<0.01)$.

Fig. (3) Correlation of each Gossypol $\rrbracket$ and control groups in correlation between Leydig cells per cluster and Leydig cells per Semineferous tubule $(P<0.01)$. 
Table (3) :Total Leydig cells per seminiferous tubule and Leydig cells found in clusters per seminiferous tubule in control and gossypol treated groups (40) $\mathrm{mg} / \mathrm{kg} \mathrm{BW}$ for (42) day.

\begin{tabular}{|c|c|c|}
\hline Parameter & $\begin{array}{c}\text { Leydig cells/ } \\
\text { seminiferous tubule }\end{array}$ & $\begin{array}{c}\text { Leydig cells in cluster/ } \\
\text { seminiferous tubule }\end{array}$ \\
\hline Control & $7.19 \pm 0.13$ & $7.65 \pm 0.20$ \\
\hline Treatment & $3.41 \pm 0.069 \mathrm{a}$ & $3.79 \pm 0.080 \mathrm{a}$ \\
\hline
\end{tabular}

Values are presented as mean \pm standard error.

Letter $\{\mathrm{a}\}:(\mathrm{P}<0.01)$ vs. Differences between treatment and control group.

The regression line of gossypol treated groups was shifted to the right for both relationships (Figure 2 and 3). This result are attributed to a similarity between the mean number of Leydig cells per semineferous tubule and the mean number of Leydig cells counted in clusters per semineferous tubule was found (table 3) where as each values were decrease in Gossypol treatment groups as compared with control group.

\section{Discussion}

Evaluations of Leydig cell density in animal and man have been almost entity confined to rough estimation based on the microscopic appearance of sections. If Leydig cells are prominent in the histological section examined, they are commonly described as hyperplasic or hypoplastic without any serious consideration of the possibility that changes many represent an artifact due to a decrease in the size of the other elements of testis or vice versa. However the effect of Gossypol on Leydig cell is unclear but we have several suggestions on direct effect on hypothalamic pituitary Leydig cell axis (Dykes, 2001).

Huang and Wang (1994) reported the effects of Gossypol on testosterone secretion. They have noticed a decrease in testosterone secretion, which was attributed to the contribution of adrenergic receptor inhibition in the hypothalamus by Gossypol this adrenergic receptor inhibition might decrease GnRH which leads to decrease of LH- Testosterone axis (Kono et al., 1991) Furthermore Leydig cell secretion act on the hypothalamus and pituitary gland through regulating the negative feedback mechanism of the quantity of GnRH release (West, 1982). Hul et al. (1993); Comhaire (1994) Huang and wang (1994) and Zhaang et al. (1994) reported that the mechanism of testosterone and estrogen releas was disrupted by Gossypol, through inhibition of hypothalamic estrogen receptor. Kalla and Sud (1990); Zhong (1990) and Udha and Pald (1992) suggested that this effect leads to increase of $\mathrm{GnRH}$ and testosterone 
levels. The increase of testosterone plays an important role in decease GnRH release through feedback mechanism and the result of $\mathrm{GnRH}$ reduction decreases testosterone secretion. On the other hands Lin et al. (1981); Olgiati et al. (1984); Gn et al. (1990); Grey et al. (1993) reported that the inhibition of testosterone release due to inhibition of LH. Receptor is dependant on adenylate cyclase-c.AMP system of Leydig cell. These results are consistent reduction in testosterone reported in this study.

The significant correlations between the three indices of Leydig cell density in this study, the number of Leydig cells per seminiferous tubule, Leydig cells per cluster and Leydig cell clusters per seminiferous tubule for the Gossypol treated and control group figures (1,2 and 3) suggest that the best index for practical clinical use would be the ratio of Leydig cell clusters per seminiferous tubules, since the correlation coefficient between total number of Leydig cells per seminiferous tubule in the entire histological section and Leydig cell clusters per seminiferous tubule was the highest (0.88). The significant correlation between the number of seminiferous tubule and clusters in the intertubular area gives further support to the suggestion that this ratio could be routinely utilized as an index of Leydig cell density.

Leydig cell hyperplasia in association with Gossypol administration was reported by Dubin and Hotchkiss (1969) and by Etriby et al., (1967). Leydig cell number in group of oligospermic rats with Gossypol treatment was apparently not increased but decreased. These studies are agreement with results of this experiment, which showed the mean number of Leydig cells per seminiferous tubule in rats' population of Gossypol treatment was lower than that reported for control rats. Further more, linear regression shift to right correlation of Leydig cells density indices give an impression to reduction the number of Leydig cell. This finding raises the question concerning the actual role of Gossypol in infertility, especially in oligospermic rats and poor motility index. The enrich results obtained by Gossypol treatment in rats suggested reduction in Leydig cell density associated with decrease testosterone level in spite of hyperplasia of Leydig cell that explained partially the suggestion reported by Al-Bayaty (1999) the Gossypol effect on hypothalamic-pituitary - Leydig cell axis.

Oshima et al., (1977) utilizing an in vitro technique, demonstrated a relationship between Leydig cell density and function. A significant correlation between testosterone synthesis and sperm motility was found. It may well be that in the Gossypol treatment rats presented here insufficient intratesticular testosterone levels resulted in impaired fertility.

Above all the critical levels needed for normal spermatogenesis as well as for adequate epididymal function in rat and human have been occurred under individual variation within narrow limited value. Dubin and Amelar (1975) employed post testosterone deficiency therapy with human chorionic 
gonadotropin. Marked improvement of semen quality and pregnancy rate was achieved. This finding supports the hypothesis that Leydig cell dysfunction, resulting in decrease intratesticular testosterone concentration, could be the mechanism responsible for poor sperm quality in these men.

Testicular androgen production therefore should be carefully evaluated in all oligospermic rats regardless of the Gossypol treatment. Determination of plasma testosterone level is not sufficient for the purpose. Direct evaluation of androgen precursors (Steinberger et al., 1970) determination of Leydig cell density and stimulation tests (human chorionic gonadotropin or clomiphene citrate stimulation test) may be required in this protocol we may be solved a part of mechanism of Gossypol dysfunction of spermatogenesis through Leydig cell density.

\section{References}

1. AI-Hassan, I. A. A \& AI-Gailany, K. A. S (1985). Biochemical studies on the seeds of Trigonella foenum - graceum. JBSR 16(1): 73-81.

2. Al-Bayaty. M. A. (1999) The Reproductive Effect of Cottonseed Extract on Male Mice PhD. College of Veterinary Medical, University of Baghdad. P 40.

3. Blandau, R.J. and Rumery, R.E. (1964). The Relationship of Swimming Movements of Epididymal Spermatozoa to their fertilizing capacity. Fertile. Steril 15: 571.

4. Brown J. (1999). The Effect of Administered Androgens on Sperm Motility. Fertile Steril. 56: 305.

5. Comhaire, F.H. (1994) Male Contraception: Hormonal, Mechanical and other Hum. Reprod 9 Suppl $2: 22-7$.

6. Dubin, L. and Amelar, R. (1975) Varicocelectomy as Therapy in Male Infertility: A Study of 504 Cases. Fertil. Steril 26: 217.

7. Dubin, L. and Hotchkiss, R.S. (1969), Testis Biopsy Subfertile Men with Varicocele Fertil steril 20: 50.

8. Dykes, J. (2001) Histometric Assessment of Human Testicular Biopsies. J. Pathol. Bacteriol. 197: 429.

9. Etriby, A.; Girgia, S.M.; Hefnawy, H. and Ibrahim, A. (1967) Testicular Changes in Subfertile Males with Varicocele. Fertil. Steril $18: 666$.

10. Gray, M.L.; Greene, L.W.; Williams, G.L. (1993), Effects of Dietary Gossypol Consumption on Metabolic Homeostasis And Reproductive Endocrine Function in Beef Heifers And Cows. J. Anim Sci 71 (11) : 3052 -3059 .

11. Gu, Z. P. Wang, Y.X.; Sang, GW; Wang, W Chen - ZX; Zhoo, Z. J.; Shao, QX; Jiang - Y (1990) Relationship Between Hormone Profiles And The Restoration of Spermatogenesis Profiles and the Restoration of 
Spermatogenesis In Men Treated With Gossypol. In J. Androl 13 (4) : 253 -7 .

12. Heller, G. and Leach DR. (1971) Quantitation of Leydig cells and measurement of Leydig cell size following administration of human chorionic gonadotrophin to normal men. J. Reprod. Fertil 25:185.

13. Hu, Y.F.; Chang, C.J. Brueggemeier, R.W. and Lin, Y.C. (1993) Gossypol Inhibits Basal and Estrogen - Stimulated DNA Synthesis.

14. Huang, H. and Wang, M. (1994) Effects of Gossypol Acetate, Danazol, Progesterone Receptors of Human Endometrial Cell and GnRH - A on Estrogen and progesterone. Chung. Kuo. Chung. His, I. chieh. Ho Tsa. Chik. 14 (6): $352-1,353$.

15. Kalla, N.R. and Sud, S. (1990) Distribution of Gossypol. Acta Eur. Fertil. 21 (2): 77- 88.

16. Kono, H.; Chin, L.; Gu. Y.; Yamaguchi, M. Zuspan, F.P.; Furuhashi; N.; Takagama. K. and Yajima, A. (1991) Gossypol Effects on Monoamine Oxidase (MAO) Activity in Several Organ of Term rat. J. Exp. Med. 163(3) : $149-1$

17. Lin. Tu.; Murono, E.P.; Osterman, J.; Howard and coulson, P.B (1981) Gossypol inhibits Testicular Steroidogenesis Fertile. Steril., 35, 5.

18. Macleod. J. (2003) The Semen Examination. Clin Obstet. Gynecol 38 : 115.

19. Olgiati, K.L.; Hoffer, A. P. and Toscanp, J.r. W.A. (1984) Gossypol Modulation of Nucleated Metabolizing Enzymes in the Reproductive tract of male mice.

20. Oshima H.; Nankin H.R.; Troen, ; Yoshid P. and Ochiai, K. (1977) Leydig Cell Number And Function in infertile Men. In The Testis in Normal and Infertile Men. Edited by P. Troen and H.R. Nankin New Raven Press P445.

21. Ridley, Alejandro and Blasco, Luis (1981) Testosterone and Gossypol Effects on Human Sperm Motility. Fertility and Sterility 36, 5 ; $638-642$.

22. Rigau, R.; Weiss, D.; Smith, K. and steinberger, E. (2000) Suggestion of Abnormal Testicular Steroidogenes in Some Oligospermic Men and Animals. Acta Endocrinal 112: 400.

23. Sakamato, J. and Hashimato, K. (1986) Reproductive toxicity of Acrylamid and Related Compounds in Mice. Effect on Fertility and Sperm Morphology. Arch. Toxicol. 95: $201-205$.

24. Smithe, K.; Tcholakian, R.; Chowdhury, M. and Steinberger, E. (1976) An Investigation of Plasma Hormone Levels Before and After Vasectomy. Fertile. Steril 27: 145.

25. Snedecor, G. and Cochran, W. (1967) Statistical Method, (6th) Edition, Ames, Iowa, Iowa state university press. 
26. Sokoloski, J. E.; Blasco, L.; Storey, B.T. and wolf, D.P. (1977) Turbidimetric Analysis of Human sperm motility. Fertile. Steril. 28, 12: $1337-1341$.

27. Steinberger E. and steinberger, A. (1972). The Testis: Basic and Clinical Aspects. In Reproductive Biology, Edited by H. Balin, S. Glasser, Amsterdam, Excerpta Medica P 144.

28. Steinberger, E. Ficher, M. and Smith, K. D. (1970) Relation of In Vitro Metabolism of Steroids in Human Testicular Tissue to Histological And Clinical Finding In the Human Testis, Edited by Rosemberg, C.A. Pauls New York and London Plenum Press P 439.

29. Steinberger, E.; Smith, K.D.; Tcholakian, RK chowdhury, M.; Steinberger, A.; Ficher, M. and Paulsen, C.A. (1973) Steroidogenesis in Human Testes. In Male Fertility and Sterility Edited by R.E. Mancini and L. Martini New York, Academic Press P 149.

30. Su - ming, Tong; Xiao - hu, Zhou and Yan - xia, Zhou (1982). Human Antifertility Effect of Gossypol Cytologic Observation of Semen. Chinese Medical Journal, 95 (5) : 355 - 362.

31. Udoh. P. and Patil. D. R. (1992) Histopathological And Biochemical effects of Gossypol Acetate on pituitary - adrenal axis in male albino rats contraception.

32. West, J.B.(1982) Best and Taylor's, physiological bases of medical practice 11 th edition, William and Wilkins Baltimore, London.

33. Zenick, H.; Clegg, E.; Perreault, S.; Klinefelter, G. and Gray, L. (1994). Assessment of Male Reproductive Toxicity. Principles and Method of Toxicology (3rd) edition; Wallace Hayes. Puplished by Raven Press Ltd, New York P 937.

34. Zhang, Y.W.; Han, M.L. and Wang. Y.F. (1994) Estrogen and Progesterone Cytosol Receptor concentrations in Patients with Endometriosis and Their Changes after Gossypol. Chang. Hua. Fu. Chan. Ko. Tsa. Chih 29,4 : $220-253$.

35. Zhong. C.Q.; Lui, Q. L.; Tang, Y.J.; Wang, Y.; Shi, F.J. and Qian, S.Z. (1990). Study on sperm function in men Long after Cassation of Gossypol Treatment. Contraception 41, 6: $617-622$. 